\title{
Feasibility on the Use of Acid Value for Evidencing the Esterification of Glycerol with Caprylic Acid Catalyzed by Lipase
}

\author{
By Michele Vitolo* \\ Juliana Neves Rodrigues Ract ${ }^{\dagger}$ \\ Sara Anunciação Braga Guebara
}

The present paper deals with the use of Acid Value (AV), a titration method largely used for fatty acid quantification, to determine the acidity of products resulting from caprylic acid (CA) and excess glycerol (GLY) esterification catalyzed by an immobilized lipase, aiming to obtain caprylins $(C L)$, as well as the blends of these two components (GLY/CA) in different proportions used as substrate for the reactions. Response surface methodology (RSM) was used to determine the effects of three variables (temperature, reaction time, and GLY/CA molar ratio) on the caprylin production optimization. The AV of the blends decreased with an increasing molar ratio GLY/CA and a coefficient variation of $11 \%$ for the AV method was obtained. The RSM did not provide a clear statistical correlation between $A V$ and the reaction parameters selected as variables. However, among all obtained AV values, $77 \%$ were in the range between 50 and $100 \mathrm{mg} \mathrm{NaOH} / \mathrm{g}$, including the experiment performed under the conditions of $60^{\circ} \mathrm{C}, 8 \mathrm{~h}$, and GLY/CA molar ratio of 2 , in which the highest caprylin production yield of about $50 \%$ was obtained.

Keywords: Acid value, Caprylic acid, Esterification, Fatty acid, Glycerol, Lipase.

\section{Introduction}

An important reaction of industrial interest at present is the esterification of glycerol, a residue largely formed during biodiesel synthesis (Freitas et al., 2009; Guebara et al., 2016), with fatty acids, in order to attain mono (MAG), di (DAG) and triacylglycerols (TAG). TAGs are the main constituents of edible oils and fats (Scrimgeour and Harwood, 2007), while MAGs and DAGs are non ionic surfactants largely used in food, pharmaceutical and cosmetic products, due to their safety for human use, as they do not cause either skin irritation or digestive problems (Da Silva et al., 2003; Machado et al., 2000; Blanco et al., 2015). MAGs, in turn, are employed as emollients in medicine formulation, emulsifiers in food products - such as margarine, dairy products, candies and sauces - and texturing agents in cosmetic formulas (creams and lotions, mainly) (Kaewthong et al., 2005). Particularly, short-chain fatty acid MAGs have specific applications. For instance, monocaprylin $\left(\mathrm{MAG}_{\mathrm{mc}}\right)$

\footnotetext{
* Professor, University of Sao Paulo, Brazil.

${ }^{\dagger}$ Professor, University of Sao Paulo, Brazil.

${ }^{\ddagger}$ Young Fellow, University of Sao Paulo, Brazil.
} 
presents antiviral, antifungal and antimicrobial activity, with valuable application in collutory (for mouth hygiene), as microbial decontaminant for textile raw materials, and as preservative against pathogens in foods (Vltavska et al., 2013; Chang et al., 2010; Garcia et al., 2007).

Traditionally, mono and diacylglycerols are obtained by a controlled glycerolysis reaction of triacylglycerols using inorganic catalysts - such as $\mathrm{Ca}(\mathrm{OH})_{2}$ and $\mathrm{NaOH}-$ at temperatures ranging from 220 to $225^{\circ} \mathrm{C}$ (Medeiros et al., 2012; Singh and Mukhopadhyay, 2014). However, an alternative to the cited procedure is the synthesis of mono and diacylglycerols by esterification of glycerol and fatty acids using immobilized lipases as a catalyst (Kittikuon et al., 2008; Zhong et al., 2014; Marzuki et al., 2015). The advantages presented by enzymatic reactions are lipase specificity, mild reaction conditions and low or nil formation of environmental unfriendly compounds (Yang et al., 2005; Solaesa et al., 2016). Moreover, literature shows that immobilized lipases present high stability against $\mathrm{pH}$, temperature, shear-force, damaging and denaturing substances, so that its catalytic capacity - by extension, its half-life - is maintained for longer periods (Minovska et al., 2005).

Lipozyme $\mathrm{RM} \mathrm{IM}^{\circledR}$ was the commercial immobilized lipase chosen as a catalyst for the esterification reaction between caprylic acid and glycerol in the present work due to some advantageous properties such as low steric hindrance on the enzyme/substrate interaction at the catalytic site, negligible change on the enzyme conformation structure and low diffusion effect during catalysis. In addition, eventual leaking of the lipase from the support is unexpected due to the low water activity and ionic concentration of the reaction medium. Finally, the same amount of enzyme can be used in reactions made either in discontinuous reactors - in this case the enzyme is separated from the medium after reaction by filtration or centrifugation - or continuous reactor, certainly leading to lower overall processing costs (Poppe et al., 2015). Undoubtedly, the esterification of glycerol with fatty acids could be inserted as an operational unit in a biodiesel producer biorefinery, in which glycerol is a residue available in huge amount (Kamm and Kamm, 2007; Herrero, et al., 2016).

Controlling an industrial process using a reliable, cheap and simple analytical method, which apparatus could be disposed and handled near the reactor in operation, would be of great interest by the industry. Two of the most employed procedures for controlling industrial processes are the Fehling titration method and the viscosity measurement, respectively, used in starch liquefaction by $\alpha$-amylase and in collagen hydrolysis by protease (Bentley and Williams, 1996; Godfrey, 1996). In this context, the present paper proposes the use of Acid Value (AV) as a parameter for the control of etherification reactions between glycerol and caprylic acid for the production of caprylins. 


\section{Materials and Methods}

\section{Materials}

Lipozyme $\mathrm{RM}^{\circledR}$ was kindly donated by Novozymes, glycerol and caprylic acid (purity $\geq 98 \%$ ) were purchased from FLUKA ${ }^{\circledR}$. All of the other chemicals used were also of the highest analytical grade.

\section{Methods}

\section{Determination of Acid Value (AV)}

The acid value of the samples $\left(\mathrm{AV}_{\mathrm{s}}\right)$ was determined by titration with $\mathrm{NaOH}$ 0.1M according to the AOCS Official Method Te 1a-64 (AOCS, 2009), with adaptations, using the following equation:

$$
\mathrm{AV}_{\mathrm{s}}=(\text { V.f.M.56) } \div \mathrm{m} \quad \text { (Eq. 1) }
$$

where $\mathrm{AV}_{\mathrm{s}}=$ Acid Value ( $\mathrm{mg}$ of $\mathrm{NaOH} / \mathrm{g}$ of sample), $\mathrm{V}=$ volume of titrant $(\mathrm{mL}), \mathrm{f}=\mathrm{NaOH}$ solution correction factor, $\mathrm{m}=$ mass of sample $(\mathrm{g})$.

\section{Determination of the Acid Value Method Precision}

The acid values $\left(\mathrm{AV}_{\mathrm{s}}\right)$ of different blends of glycerol and caprylic acid (GLY:CA) at the proportions of 1:1, 2:1, 3:1, 4:1 and 5:1 were measured, as well as the acid values of pure glycerol (GLY) and caprylic acid (CA). The precision of the AV method was evaluated using two blends composed by GLY and CA at the proportion of 3:1, both prepared independently but under the same conditions. Five aliquots from each solution were collected. Then, solvent solutions, namely Solution I (water, acetic acid and petroleum ether), Solution II (water, absolute ethanol and n-heptane), and Solution III (water, absolute ethanol and n-hexane), at the proportion of 1:1:2 were added to the GLY:CA 3:1 blend, one by one, and vigorously shaken in a pear-type glass separation funnel. The AV was measured in the upper phase (organic) and in the bottom phase (inorganic). The mean AV values of the two blends were compared using the conventional statistical "t-student" test.

\section{Experimental Design and Optimization by Response Surface Method (RSM)}

A three-level, three factorial Central Composite Rotable Design (CCRD) was employed in this study, requiring 17 experiments. The fractional factorial design consisted of 8 factorial points, 6 axial points, and 3 center points. The variables and their levels selected for optimizing the percent yield of reaction for monocaprylin $\left(\mathrm{Y}_{\mathrm{m}}\right)$ or dicaprylin $\left(\mathrm{Y}_{\mathrm{d}}\right)$ or the sum of them $\left(\mathrm{Y}_{\mathrm{md}}\right)$ were as follows: reaction temperature $\left(60-80^{\circ} \mathrm{C}\right)$, reaction time $(4-8 \mathrm{~h})$, and substrate mole ratio [(GLY:CA) 2:1 - 4:1] (Koh et al., 2010). The data from the 
experiments performed were analyzed using Statistica vesion 9.0 (Statsoft) and then interpreted by plotting the response surfaces aiming to stablish an optimum condition for the esterification reaction. The goodness of fit model was evaluated by the coefficient of determination $\left(\mathrm{R}^{2}\right)$. The 3D surface plots were developed using the fitted reduced cubic (modified model) polynomial equations obtained by selecting the central value of each independent variable, two by two (Rodrigues and Iemma, 2009).

Table 1. Central Composite Rotational Design for a Three-level, Three-factor Response Surface Analysis used for Optimizing the Yields of Formation of Monocaprylin $\left(Y_{m}\right)$, Dicaprylin $\left(Y_{d}\right)$, and their Sum $\left(Y_{m d}\right)$

\begin{tabular}{|c|c|c|c|}
\hline $\begin{array}{c}\text { Tests } \\
\text { (n.) }\end{array}$ & $\begin{array}{c}\text { Temperature } \\
\left({ }^{\circ} \mathrm{C}\right)\end{array}$ & $\begin{array}{l}\text { Reaction time } \\
\text { (h) }\end{array}$ & Glycerol/caprylic acid mole ratio (\%) \\
\hline 1 & 60 & 4 & 2 \\
\hline 2 & 80 & 4 & 2 \\
\hline 3 & 60 & 8 & 2 \\
\hline 4 & 80 & 8 & 2 \\
\hline 5 & 60 & 4 & 4 \\
\hline 6 & 80 & 4 & 4 \\
\hline 7 & 60 & 8 & 4 \\
\hline 8 & 80 & 8 & 4 \\
\hline 9 & 50 & 6 & 3 \\
\hline 10 & 90 & 6 & 3 \\
\hline 11 & 70 & 2 & 3 \\
\hline 12 & 70 & 10 & 3 \\
\hline 13 & 70 & 6 & 1 \\
\hline 14 & 70 & 6 & 5 \\
\hline 15 & 70 & 6 & 3 \\
\hline 16 & 70 & 6 & 3 \\
\hline 17 & 70 & 6 & 3 \\
\hline
\end{tabular}

\section{Batch Synthesis of Caprylins}

Lipase-catalyzed synthesis of caprylins was carried out with $50 \mathrm{~g}$ batch reaction mixtures composed of caprylic acid and glycerol at various ratios using $5 \mathrm{~g}$ of Lipozyme RM inside a $100 \mathrm{~mL}$ round glass flask. The flask was adapted to a rotary evaporator at $180 \mathrm{rpm}$ coupled to a vacuum pump (suction capacity of $0.6 \mathrm{~m}^{3} / \mathrm{h}$ and final vacuum of $8 \mathrm{mbar}$ ), in order to remove water formed during the esterification process, and maintained partially submersed in a water bath at the desired temperature. The experiments were done according to the three-level, three factorial CCRD experimental design. The reaction was interrupted by filtration of the lipase from the reaction medium. The samples were subsequently purified and then analyzed for caprylin identification and quantification by gas chromatography. All the reactions were performed in duplicate. The reaction products were washed with solutions I, II and III, as well as the 1:3 GLY:CA blends, as previously described in item 2.3. 


\section{Determination of Caprylins}

Tricaprylin $\left(\mathrm{TAG}_{\mathrm{c}}\right)$, dicaprylin $\left(\mathrm{DAG}_{\mathrm{c}}\right)$ and monocaprylin $\left(\mathrm{MAG}_{\mathrm{c}}\right)$ were identified on a gas liquid chromatograph Varian GC, model 3400CX, equipped with split-injection port, flame-ionization detector, Star Chromatography Workstation and a $15 \mathrm{~m}$ capillary column (ID $=0.25 \mathrm{~mm}$ ) filled with $0.15 \mu \mathrm{m}$ phenyl-methylpolysiloxane DB-17HT (Agilent). The helium carrier gas flow was $1.0 \mathrm{~mL} / \mathrm{min}$ at a split ratio of $30: 1$. The injector temperature was $360^{\circ} \mathrm{C}$, the detector temperature was $375^{\circ} \mathrm{C}$ and the oven was set to increase its temperature from $80^{\circ} \mathrm{C}$ up to $350^{\circ} \mathrm{C}$ at a rate of $5^{\circ} \mathrm{C} / \mathrm{min}$. After drawing up some air into the filled syringe (sample volume $1 \mu \mathrm{L}$ ) and inserting the needle into the heated injector, samples were injected manually. Qualitative caprylin composition was accomplished by area normalization, expressed as percent $\mathrm{w} / \mathrm{w}$, by comparing the retention times of the peaks with the respective standards of mono, di, and tricaprylin, as well as free caprylic acid. Samples were run in duplicate and the values were averaged.

\section{Results}

The precision of the acid value method was evaluated using the conventional statistical "t-student" test, presented in Table 2. According to Levin (1977) the "t-student" value can be calculated by the following equations:

$$
\begin{aligned}
& \sigma_{\text {dif }}=\left[\left(\sigma_{\mathrm{I}}\right)^{2}+\left(\sigma_{\mathrm{II}}\right)^{2}\right]^{1 / 2} \\
& \mathrm{t}_{\text {calc }}=\left|\mathrm{X}_{\mathrm{mI}}-\mathrm{X}_{\mathrm{mII}}\right| \div \sigma_{\text {dif }}
\end{aligned}
$$

By applying the parameters shown in Table 2 in equations 2 and 3, the following numerical values were calculated: $\sigma_{\text {dif }}=9.62$ and $t_{\text {calc }}=0.582$. With a $99 \%$ of confidence and a freedom degree of 8 , then $t_{\text {tabulated }}=3.355$ (Levin, 1977). As $t_{\text {calc }}<t_{\text {tabulated }}$ there was no significant difference between the average $A V_{\text {total }}$ values of blends I and II. Thereby, the average acid value $\left(\mathrm{AV}_{\mathrm{av}}\right)$ and the coefficient of variation $(\mathrm{CV})$ were $\mathrm{AV}_{\mathrm{av}}=126.42 \pm 13.899(\mathrm{mg} \mathrm{NaOH} / \mathrm{g})$ and $\mathrm{CV}=11 \%$. 
Table 2. Total Acid Value (AV $\left.V_{\text {Total }}\right)$ of Blends I and II in the Proportion 3:1 (GLY:CA) and the Fundamental Parameters for the Statistical "t-student" Test

\begin{tabular}{|c|c|c|c|c|}
\hline \multicolumn{2}{|l|}{ Parameters } & Blend I & \multicolumn{2}{|c|}{ Blend II } \\
\hline \multirow{5}{*}{\multicolumn{2}{|c|}{$\mathrm{AV}_{\text {Total }}(\mathrm{mg} \mathrm{NaOH} / \mathrm{g})$}} & 142.7 & \multicolumn{2}{|c|}{115.8} \\
\hline & & 133.4 & \multicolumn{2}{|c|}{117.1} \\
\hline & & 148.8 & \multicolumn{2}{|c|}{129.3} \\
\hline & & 97.1 & \multicolumn{2}{|c|}{132.4} \\
\hline & & 124.1 & \multicolumn{2}{|c|}{123.5} \\
\hline$\Sigma \mathbf{x}^{*}$ & & 646.1 & \multicolumn{2}{|c|}{618.1} \\
\hline $\mathbf{X}_{\mathrm{m}}=(\Sigma \mathrm{x}) / \mathbf{N}^{* *}\{\mathrm{~N}=5\}$ & & 129.22 & \multicolumn{2}{|c|}{123.62} \\
\hline $\mathbf{X}_{\mathrm{m}}^{2}$ & & $16,697.81$ & \multicolumn{2}{|c|}{$15,281.90$} \\
\hline$\Sigma \mathrm{x}^{2}$ & & $85,129.51$ & \multicolumn{2}{|c|}{$76,622.55$} \\
\hline s**** & & 18.11 & \multicolumn{2}{|c|}{6.52} \\
\hline$\sigma^{* * * *}$ & & 9.055 & \multicolumn{2}{|c|}{3.26} \\
\hline \multicolumn{5}{|c|}{$\begin{array}{l}* \mathrm{x}=\text { each } \mathrm{AV}_{\text {Total }} \text { value; } \Sigma \mathrm{x}=\text { sum of } \mathrm{AV}_{\text {Total }} \text { for each blend; } * * \mathrm{~N}=\text { number of replicates; } * * * \mathrm{~s} \\
(\text { standard deviation })=\left[\left(\sum \mathrm{x}^{2} / \mathrm{N}\right)-\mathrm{X}_{\mathrm{m}}{ }^{2}\right]^{1 / 2} ; * * * * \sigma(\text { standard error })=\left[\mathrm{s} \div(\mathrm{N}-1)^{1 / 2}\right]\end{array}$} \\
\hline \multicolumn{5}{|c|}{$\begin{array}{l}\text { Table } 3 \text { shows the samples }\left(A V_{s}\right) \text { and theoretic }\left(A V_{\text {th }}\right) \text { acid values } \\
\text { regarding the GLY:CA blends at proportions of } 1: 1,2: 1,3: 1,4: 1 \text { and } 5: 1 \text {. }\end{array}$} \\
\hline \multicolumn{5}{|c|}{$\begin{array}{l}\text { Table 3. Relative Dilutions of Caprylic Acid in relation to Glycerol, the } \\
\text { Sample }\left(A V_{s}\right) \text { and Theoretical }\left(A V_{t h}\right) \text { Acid Values for Each Blend }\end{array}$} \\
\hline $\begin{array}{l}\text { Glycerol/caprylic acid } \\
\text { proportion }\end{array}$ & $\mathrm{CAD}^{*}$ & $\begin{array}{c}\mathrm{AV}_{\mathrm{s}} \\
(\mathrm{mg} \mathrm{NaOH} / \mathrm{g})\end{array}$ & $\begin{array}{c}\mathrm{AV}_{\text {th }} \\
(\mathrm{mg} \mathrm{NaOH} / \mathrm{g})\end{array}$ & $\begin{array}{l}\mathrm{AV}_{\mathrm{th}} / \mathrm{AV}_{\mathrm{s}} \\
(\%)\end{array}$ \\
\hline $1: 1$ & $2 \mathrm{X}$ & 206.5 & 188.7 & 8,62 \\
\hline $2: 1$ & $3 X$ & 150.9 & 159.7 & 5.50 \\
\hline $3: 1$ & $4 X$ & 134.4 & 119.8 & 10.9 \\
\hline $4: 1$ & $5 X$ & 104.1 & 95.8 & 8.00 \\
\hline $5: 1$ & $6 \mathrm{X}$ & 89.6 & 79.8 & 10.9 \\
\hline
\end{tabular}

$* \mathrm{CAD}=$ Caprylic acid dilution in relation to glycerol

The $\mathrm{AV}_{\mathrm{s}}$ of both the aqueous and solvent phases of the GLY:CA blend at the proportion of 3:1 submitted to extraction operations with solutions composed of water, absolute ethanol and n-hexane (or n-heptane) or water, acetic acid and petroleum ether were measured and the results are shown in Table 4. The acid value of pure glycerol and caprylic acid were $2.0 \mathrm{mg}$ $\mathrm{NaOH} / \mathrm{g}$ and 375,4 $\mathrm{mg} \mathrm{NaOH} / \mathrm{g}$, respectively, and are presented in Table 4. 
Table 4. Acid Values $\left(A V_{s}\right)$ of Pure Glycerol and Caprylic Acid, Extraction Solvent Solutions I (Water, Acetic Acid and Petroleum Ether), II (Water, Absolute Ethanol and n-heptane), III (Water, Absolute Ethanol and n-hexane), and for the Upper and Bottom Phases of Glycerol/Caprylic Acid Blend 3:1 after Separation with Solvent Solutions I, II, and III

\begin{tabular}{lcc}
\hline Phase & $\mathrm{AV}_{\mathrm{S}}(\mathrm{mg} \mathrm{NaOH} / \mathrm{g})$ & $* \mathrm{AV}_{\text {total }}(\mathrm{mg} \mathrm{NaOH} / \mathrm{g})$ \\
\hline Glycerol $_{\text {pure }}$ & 2.00 & 373.6 \\
Caprylic acid $_{\text {pure }}$ & 371.6 & \\
\hline Solution I & 28.4 & 28.4 \\
Solution II & 7.05 & 7.05 \\
Solution III $_{\text {Phase }_{\text {upper }} \text { I }}$ & 4.56 & 3.56 \\
Phase $_{\text {bottom I }}$ & 308.4 & 320.8 \\
\hline Phasee $_{\text {upper }}$ II & 12.35 & 293.7 \\
Phase $_{\text {bottom II }}$ & 281.5 & 317.5 \\
Phase $_{\text {upper }}$ III & 12.21 & \\
Phase $_{\text {bottom III }}^{*} \mathrm{AV}_{\text {Total }}$ is the sum of $\mathrm{AV}_{\mathrm{s}}$ referred to the upper and bottom phases, as well as the pure glycerol \\
and caprylic acid.
\end{tabular}

Table 5. Total Acid Value (AV $V_{\text {Total }}$ ) of 3:1 Glycerol/Caprylic Acid Blend submitted to Extraction with Solutions I, II, and III and Fundamental Parameters for the Variance Analysis ("test F")

\begin{tabular}{lccc}
\hline Parameters & Solution I & Solution II & Solution III \\
\hline & 29.09 & 53.65 & 29.08 \\
\cline { 2 - 4 } & 29.08 & 66.07 & 31.07 \\
\cline { 2 - 4 } $\mathrm{AV}_{\text {Total }}$ & 29.17 & 48.65 & 22.17 \\
\cline { 2 - 4 } & 29.51 & 46.82 & 63.08 \\
\hline $\mathrm{mg} \mathrm{NaOH} / \mathrm{g})$ & 30.32 & 48.64 & 59.55 \\
\hline$\Sigma \mathrm{x}^{*}$ & 147.17 & 263.83 & 204.95 \\
\hline$(\Sigma \mathrm{x}) / \mathrm{N}\{\mathrm{N}=5\}$ & 29.43 & 52.77 & 40.99 \\
\hline$\left(\sum \mathrm{x}\right)^{2} / \mathrm{N}\{\mathrm{N}=5\}$ & $4,331.80$ & $13,921.25$ & $8,400.90$ \\
\hline$\Sigma \mathrm{x}^{2}$ & $4,332.91$ & $14,168.34$ & $9,827.79$ \\
\hline$\left(\sum \mathrm{x}^{2}\right)_{\text {total }}=28,329.04$ & & & \\
\hline$(\Sigma \mathrm{x})_{\text {total }}=37,9394.4$ & & & \\
\hline$* \mathrm{x}$ & & & \\
\hline
\end{tabular}

*x represents each $\mathrm{AV}_{\text {Total }}$ values and $\Sigma \mathrm{x}=$ summation of $\mathrm{AV}_{\text {Total }}$ for each extraction solution

A blend of glycerol and caprylic acid at a proportion of 3:1 was submitted to the extraction with the solutions I, II and III mentioned above. Five aliquots of the mixture were extracted with each one of these solutions and the correspondent $A V_{\text {total }}$ was measured (Table 5). According to Levin (1977), the $F$ value can be calculated by the following equations:

$$
\mathrm{SS}_{\mathrm{t}}=\left(\Sigma \mathrm{x}^{2}\right)_{\text {total }}-\left[(\Sigma \mathrm{x})^{2}{ }_{\text {total }} / \mathrm{N}_{\mathrm{t}}\right]
$$

where $\mathrm{N}_{\mathrm{t}}=$ total number of $\mathrm{AV}_{\text {total }}$ determinations (in this case, $\mathrm{N}_{\mathrm{t}}=15$ ); $\mathrm{SS}_{\mathrm{t}}=$ Total square summation. 


$$
\begin{aligned}
& \mathrm{SS}_{\mathrm{e}}=\left\{\Sigma\left[\left(\sum \mathrm{x}\right)^{2} / \mathrm{N}\right]-\left[\left(\sum \mathrm{x}\right)_{\text {total }}^{2} / \mathrm{N}_{\mathrm{t}}\right]\right\} \\
& \mathrm{SS}_{\mathrm{d}}=\mathrm{SS}_{\mathrm{t}}-\mathrm{SS}_{\mathrm{e}} \\
& \mathrm{F}_{\text {calc }}=\left(\mathrm{SS}_{\mathrm{e}} / \mathrm{gl}_{\mathrm{e}}\right) \cdot\left(\mathrm{gl}_{\mathrm{d}} / \mathrm{SS}_{\mathrm{d}}\right)
\end{aligned}
$$

where $\mathrm{gl}_{\mathrm{e}}=$ freedom degree inter-groups (in this case $\mathrm{gl}_{\mathrm{e}}=2$ ); $\mathrm{gl}_{\mathrm{d}}=$ freedom degree intra-groups (in this case $\mathrm{gl}_{\mathrm{d}}=12$ ); $\mathrm{SS}_{\mathrm{e}}=$ inter-group square summation; $\mathrm{SS}_{\mathrm{d}}=$ intra-group square summation.

By applying the parameters shown in Table 4 in equations 4-7, the following numerical values were calculated: $\mathrm{SS}_{\mathrm{t}}=3,036.08 ; \mathrm{SS}_{\mathrm{e}}=1,361.04$; $\mathrm{SS}_{\mathrm{d}}=1,675.04$ and $\mathrm{F}_{\text {calc }}=4.88$. At $95 \%$ of confidence and for $\mathrm{gl}_{\mathrm{e}}=2$ and $\mathrm{gl}_{\mathrm{d}}=$ 12 the $F_{\text {tabulated }}=3.88$ (Levin, 1977). As $F_{\text {calc }}>F_{\text {tabulated }}$ there was a significant difference between the average $A V_{\text {total }}$ resulted from using solutions I, II and III to separate glycerol and caprylic acid.

Table 6 presents $\mathrm{AV}_{\mathrm{s}}$ results and the caprylin composition (proportion of $\mathrm{TAG}_{\mathrm{c}}, \mathrm{DAG}_{\mathrm{c}}, \mathrm{MAG}_{\mathrm{c}}$ and CA) of the products obtained by esterification of glycerol with caprylic acid under the reaction conditions indicated in Table 1.

Table 6. Acid Values $\left(A V_{s}\right)$ and Percent Acylglycerols (TAG, DAG and MAG) resulted from the Esterification of Glycerol with Caprylic Acid Carried out according to the CCRD

\begin{tabular}{ccccccc}
\hline $\begin{array}{c}\text { Test } \\
(\mathbf{n} .)\end{array}$ & $\begin{array}{c}\mathbf{A V}_{\mathbf{s}} \\
(\mathbf{m g ~ N a O H / g})\end{array}$ & $\begin{array}{c}\mathbf{C A}^{*} \\
(\boldsymbol{\%})\end{array}$ & $\begin{array}{c}\text { MAG } \\
(\boldsymbol{\%})\end{array}$ & $\begin{array}{c}\text { DAG } \\
(\boldsymbol{\%})\end{array}$ & $\begin{array}{c}\text { TAG } \\
(\boldsymbol{\%})\end{array}$ & $\begin{array}{c}\text { TA** } \\
(\boldsymbol{\%})\end{array}$ \\
\hline 1 & 92.4 & 66.9 & 7.9 & 21.5 & 3.6 & 33.1 \\
2 & 137.4 & 98.7 & 0 & 0.1 & 1.2 & 1.3 \\
3 & 70.7 & 49.3 & 20.0 & 26.6 & 4.0 & 50.7 \\
4 & 122.4 & 94.2 & 0.3 & 5.1 & 0.4 & 5.8 \\
5 & 64.9 & 86.7 & 0 & 10.8 & 2.5 & 13.3 \\
6 & 75.7 & 91.0 & 0 & 8.3 & 0.7 & 9.0 \\
7 & 58.1 & 96.7 & 0.1 & 3.0 & 0.1 & 3.3 \\
8 & 72.8 & 88.9 & 0.4 & 6.7 & 0.3 & 7.4 \\
9 & 88.0 & 91.2 & 0.8 & 7.3 & 0.7 & 8.8 \\
10 & 77.2 & 95.9 & 0.3 & 3.5 & 0.3 & 4.1 \\
11 & 89.8 & 96.3 & 0 & 3.2 & 0.5 & 3.7 \\
12 & 90.3 & 96.5 & 0 & 3.1 & 0.3 & 3.5 \\
13 & 237.9 & 96.9 & 0 & 2.6 & 0.3 & 3.2 \\
14 & 31.6 & 67.7 & 1 & 29.1 & 1.9 & 32.3 \\
15 & 96.8 & 95.9 & 0 & 3.3 & 0.4 & 4.1 \\
16 & 100.8 & 94.4 & 0.3 & 4.8 & 0.4 & 5.5 \\
17 & 92.4 & 94.9 & 0.4 & 4.4 & 0.3 & 5.1 \\
\hline
\end{tabular}

*CA = Caprylic Acid; **TA= Total Acylglycerols 


\section{Discussion}

The low acid value found for pure glycerol $(2.0 \mathrm{mg} \mathrm{NaOH} / \mathrm{g}$ ) can be explained by the weak acid character presented by the hydrogen atoms bonded to three very electronegative oxygen atoms, which readily accommodate the negative charge of the electrons left behind (Morrison and Boyd, 1969).

Table 3 shows that as the proportion of glycerol in relation to caprylic acid increases, the acid values $\left(\mathrm{AV}_{\mathrm{s}}\right)$ of the blends decrease. The same occurs with the theoretical acid value $\left(\mathrm{AV}_{\mathrm{th}}\right)$. This behavior could be explained assuming that the caprylic acid is diluted as the glycerol amount was increased into the mixture. For instance, the caprylic acid is two and six times diluted at the ratios glycerol/caprylic acid of $1: 1$ and 5:1, respectively. Taking into account the percent variation of the ratio $\mathrm{AV}_{\mathrm{th}} / \mathrm{AV}_{\mathrm{s}}(5.5 \%-10.9 \%)$, such variation was in accordance with the coefficient of variation of the analytical method $(11 \%)$. However, the decreasing of $\mathrm{AV}_{\mathrm{s}}$ was not proportional to the dilution of caprylic acid, since the $\mathrm{AV}_{\mathrm{s}}$ for the 1:1 GLY:CA blend $(206.5 \mathrm{mg} \mathrm{NaOH} / \mathrm{g})$ is 2.3 times higher than for $5: 1$ blend $(89.6 \mathrm{mg} \mathrm{NaOH} / \mathrm{g})$ instead of three times. Probably, a fraction of caprylic acid molecules were not available to neutralization by $\mathrm{NaOH}$ due to intermolecular interactions with glycerol molecules by weak chemical bonds such as hydrogen bond (Silva et al., 2015).

The particular composition of each extraction solution led to different $\mathrm{AV}_{\mathrm{s}}$ for the GLY:CA blend 3:1, of which the highest was obtained for solution I (28.4 $\mathrm{mg} \mathrm{NaOH} / \mathrm{g}$ ), as presented in Table 4 . Of course, the presence of acetic acid in solution I explains why the AV of the 3:1 blend washed with this solution was $75 \%$ and $84 \%$ higher than the ones washed with solutions II and III, respectively. However, when acetic acid was not present in the solvent solution (solutions II and III), $\mathrm{AV}_{\mathrm{s}}$ in all upper phases would be due to the retention of some amount of caprylic acid into the interface and/or its unavailability for titration with $\mathrm{NaOH}$ due to chemical interactions with other compounds present in the extraction system.

The average $\mathrm{AV}_{\text {total }}$ of the 3:1 GLY:CA blends determined after the separation procedures with solutions I, II and III presented significant difference, as observed with the variance analysis (Table 5). According to Levin (1977), when a significant " $F$ " related to the differences of three or more means is found - in this work $A V_{\text {total }}$ means resulted from the use of three different extraction solutions -, it could be interesting to analyze whether the high difference found, of $23.34 \mathrm{mg} \mathrm{NaOH} / \mathrm{g}$, - between the extractions carried out with solution II $\left(\mathrm{AV}_{\mathrm{m}}=52.77 \mathrm{mg} \mathrm{NaOH} / \mathrm{g}\right)$ and $\mathrm{I}\left(\mathrm{AV}_{\mathrm{m}}=29.43 \mathrm{mg}\right.$ $\mathrm{NaOH} / \mathrm{g}$ ) - is or not significant. The statistic "Difference Honestly Significant (DHS)", known as Tukey test, is highly recommended for this purpose. The Tukey test is based on the DHS calculation using the equation:

$$
\mathrm{DHS}=\mathrm{q}_{\alpha} \cdot\left(\mathrm{MS}_{\mathrm{d}} / \mathrm{N}\right)^{1 / 2} \quad(\text { Eq. } 8)
$$

where $\mathrm{MS}_{\mathrm{d}}=\mathrm{SS}_{\mathrm{d}} / \mathrm{gl}_{\mathrm{d}} ; \mathrm{q}_{\alpha}=3.77$ (at $95 \%$ confidence level; Levin, 1977) and $\mathrm{N}$ $=5$. By applying equation 8 , DHS $=19.92$. 
As DHS < 23.34, the most significant difference occurred when the 3:1 GLY:CA blend was submitted to extraction with solutions I and II. Probably, the different nature of the hydrocarbons present in solution I (petroleum ether is a combination of $\mathrm{C}_{5}$ and $\mathrm{C}_{6}$ alkanes) nad II (n-heptane; $\mathrm{C}_{7}$ ) explains the different extractive capability of both solutions.

As exposed in Table 6, the formation of MAG, DAG and TAG depended on the conditions under which the esterification was carried out. The assay conditions of test $14\left(70^{\circ} \mathrm{C}\right.$, reaction time of $6 \mathrm{~h}$ and GLY:CA proportion of 2:1) led preferentially to the DAG synthesis $(29.1 \%)$, whereas in test $3\left(60^{\circ} \mathrm{C}\right.$, reaction time of $8 \mathrm{~h}$ and GLY:CA proportion of 2:1), all types of caprylins were formed (DAG > MAG > TAG). However, in all tests, except for test 2, apparently carried out under the worst esterification conditions $\left(80^{\circ} \mathrm{C}\right.$, reaction time of $4 \mathrm{~h}$ and GLY:CA proportion of 2:1), DAGs were always formed. This result could be due to the sn-1,3 specificity presented by the lipase employed as a catalyst, as informed by the producer.

Table 6 also shows the acid values of the products obtained with the esterification reactions between GLY and CA carried out according to the CCRD presented in Table 1. The response surface methodology (RSM) showed an acid value (AV) significantly dependent on the GLY:CA mole ratio, as revealed by the $F$ values regarding either the quadratic $\left(F_{Q}=5.44263\right)$ or linear $\left(F_{L}=70.7423\right)$ model (Table 7$)$. The AV dependence on GLY:CA mole ratio is thoroughly corroborated by the fact that $\mathrm{F}_{\text {tabulated }}=3.88$ (Levin, 1977) was lower than $\mathrm{F}_{\mathrm{Q}}$ and $\mathrm{F}_{\mathrm{L}}$.

Table 7. ANOVA related to the Acid Value after the Esterification Reaction

\begin{tabular}{l|c|c}
\hline Factor & F value & P \\
\hline Time $(\mathrm{Q})^{*}$ & $0.35716^{\mathrm{b}}$ & $0.555683^{\mathrm{b}}$ \\
Time (L)** & $0.45952^{\mathrm{b}}$ & $0.504333^{\mathrm{b}}$ \\
Temperature (Q) & $1.18429^{\mathrm{b}}$ & $0.287293^{\mathrm{b}}$ \\
Temperature (L) & $2.24962^{\mathrm{b}}$ & $0.146688^{\mathrm{b}}$ \\
Reactant proportion (Q) & $5.44263^{\mathrm{a}}$ & $0.028361^{\mathrm{a}}$ \\
Reactant proportion (L) & $70.7423^{\mathrm{a}}$ & $0.000000^{\mathrm{a}}$ \\
\hline
\end{tabular}

${ }^{*} \mathrm{Q}=$ quadratic; $* * \mathrm{~L}=$ linear; ${ }^{\mathrm{a}}$ Significant value; ${ }^{\mathrm{b}}$ Insignificant value

The coefficient of determination $\left(\mathrm{R}^{2}\right)$ calculated using ANOVA was 0.78469. Such value, at first glance, could indicate that the statistical model chosen was not adequate. However, as a great number of assays were carried out - a total of 34 , since each test was performed in duplicate $-R^{2}$ as low as 0.349 should be acceptable, according to Fowlie (1969). Thereby, the model used could be considered adequate.

In addition, the small number of variables taken into account (time, temperature and GLY:CA mole ratio) contributed to decrease $\mathrm{R}^{2}$. According to $\mathrm{Xu}$ et al., (1998) and Koh et al., (2010) five variables should probably be enough to improve the final $\mathrm{R}^{2}$ value. However, Koh et al., (2010) enhances that introducing a high number of variables in the CCRD could result in increased $\mathrm{R}^{2}$ values, even though the model could be considered not 
significant. In other words, a high $\mathrm{R}^{2}$ does not necessarily indicate as adequate model.

Figure 1 shows the response surface correlating the reaction time and the GLY:CA mole ratio with the acid values (AV). It reveals that the best correlation occurred with the AV values lower than 32 . However, under this condition the initial amount of glycerol might be so high that the reaction would practically become unviable due to the high viscosity of the medium as well as the difficulties for purifying the products formed (mono and dicaprylins, mainly).

Figure 1. Response Surface Correlating Reaction Time and Mole Proportion with Acid Value

Fitted Surf ace; Variable: IA

3 factors, 1 Blocks, 34 Runs; MS Residual=562,0056

DV: IA

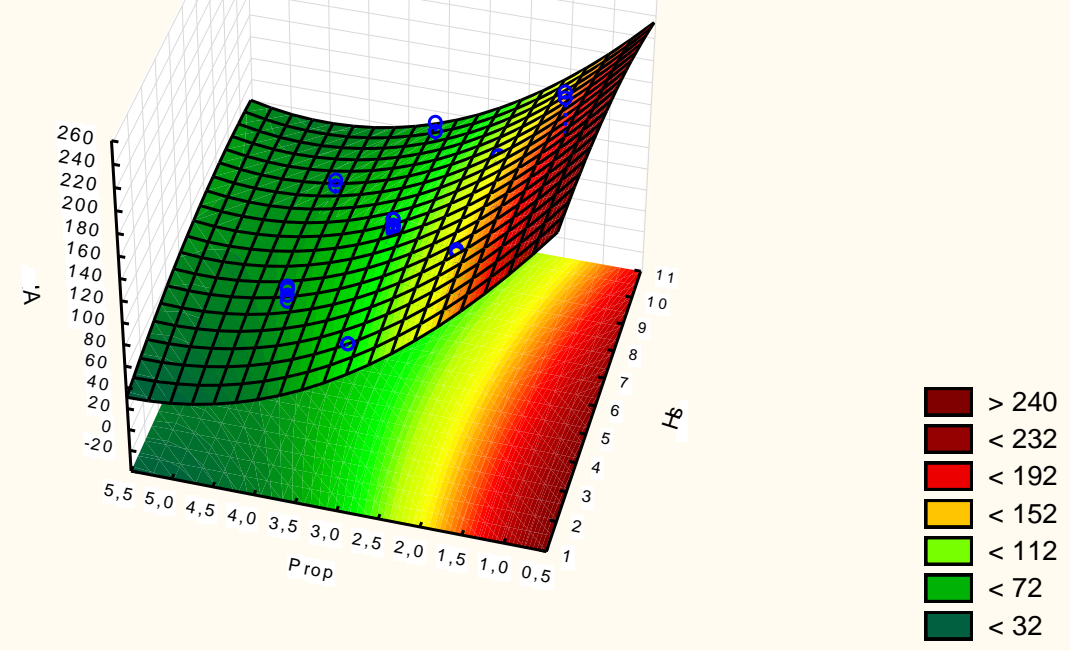

Figure 2 shows the effect of temperature and the GLY:CA mole ratio on the acid value. The best yield would occur at high glycerol concentrations and low temperatures. This result indicates an antagonism of these parameters on the reaction, as low temperatures $\left(45-55^{\circ} \mathrm{C}\right)$ are recommended for lipase stability, but high glycerol concentrations would lead to an unfeasible reaction medium viscosity, for instance, as previously discussed.

Figure 3 shows the effect of the temperature and reaction time on the acid value. It is clear that the simultaneous effect of the reaction time and temperature was insignificant, because all points are situated in the red zone, pointing to high values of $\mathrm{AV}$, i.e., high initial caprylic acid concentration. Table 7 presents $\mathrm{p}>0.05$, which indicates that the factors considered negatively affected the reaction yields. 
Finally, the predicted and observed acid values were plotted in Figure 4. It is clear that the experimental results did not fit well in the prediction line, reflecting the data obtained by RSM, by which no clear correlation between acid value and the variables studied was found. However, a cloud of experimental points was formed in the interval from $50 \mathrm{mg} \mathrm{NaOH} / \mathrm{g}$ to $100 \mathrm{mg}$ $\mathrm{NaOH} / \mathrm{g}$ (Figure 4). Considering the data shown in Table 6, it is possible to observe that only four tests (numbers 2, 4, 13 and 14) had their AVs beyond the cited interval. Despite the fact that a clear connection between the variables did not occur, the tendency of $77 \%$ among all tests directs to the prediction line (Figure 4). Thereby, the use of AV as a measurement method to follow up the formation of caprylins could probably be better envisaged if the ranges chosen for the variables in the experimental design, namely temperature, reaction time, and GLY:CA mole ratio, were finely tuned in.

Figure 2. Response Surface Correlating Temperature and Mole Proportion with Acid Value

Fitted Surf ace; Variable: IA

3 factors, 1 Blocks, 34 Runs; MS Residual=562,0056

DV: IA

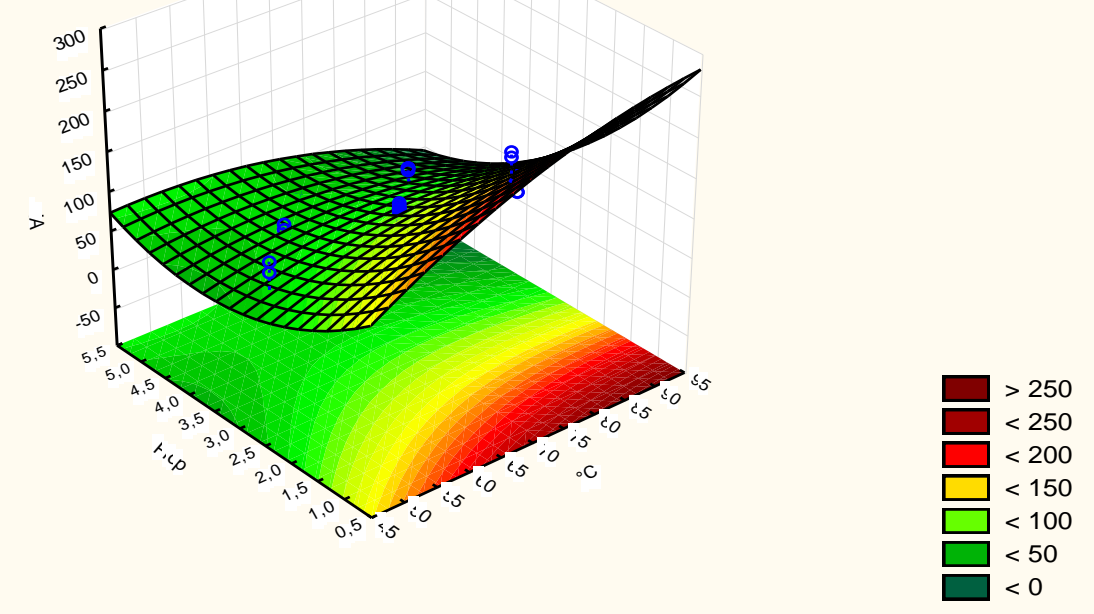


Figure 3. Response Surface Correlating Temperature and Reaction Time with Acid Value

Fitted Surf ace; Variable: IA

3 factors, 1 Blocks, 34 Runs; MS Residual=562,0056

DV: IA

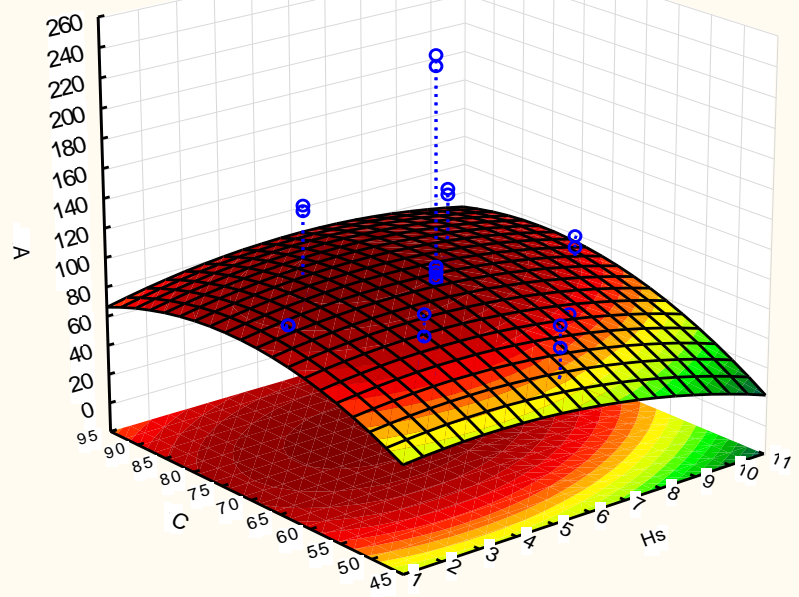

Figure 4. Correlation between Acid Value Predicted and Experimentally Obtained Data

Observed vs. Predicted Values

3 factors, 1 Blocks, 34 Runs; MS Residual=562,0056

DV: IA

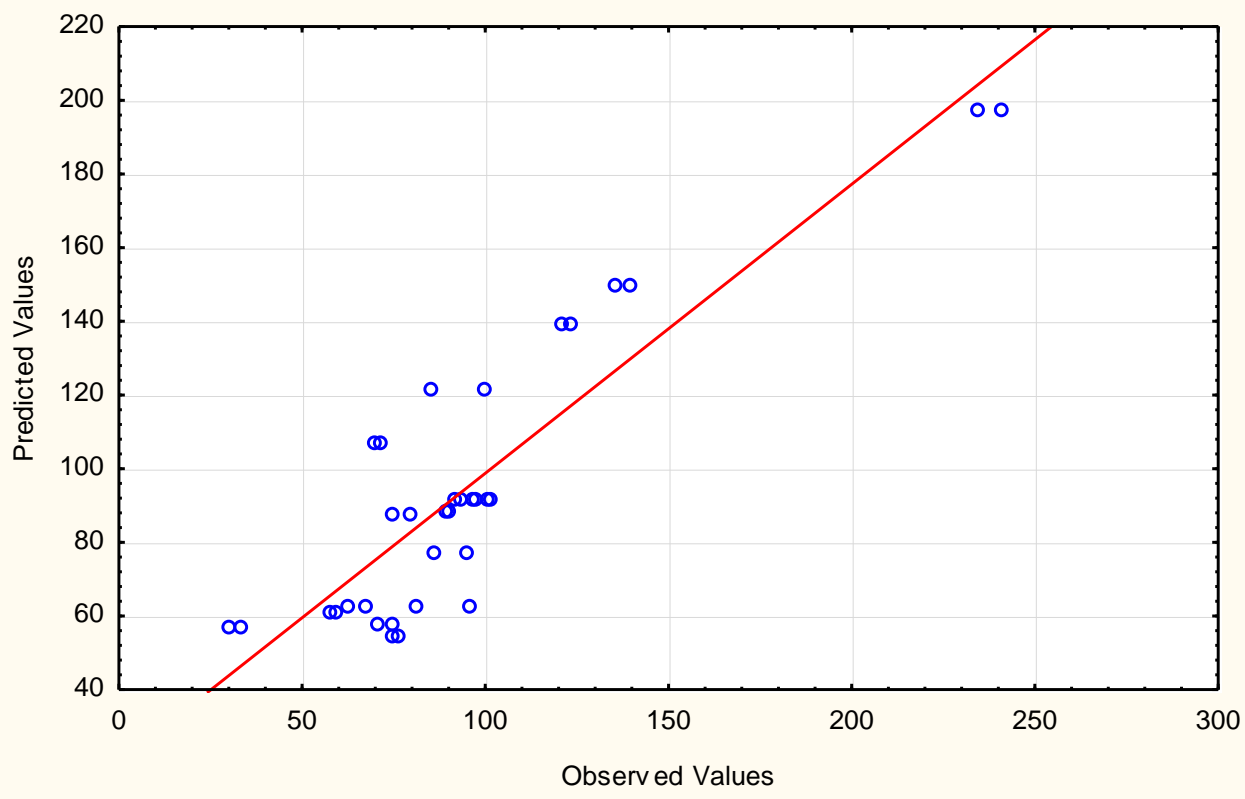




\section{Conclusions}

The data obtained led to the conclusion that the acid value (AV) could be considered a rough parameter for controlling the reaction between glycerol and caprylic acid catalyzed by commercial immobilized lipases (LIPOZYME ${ }^{\circledR}$ ). When AV was used for determining the acidity of glycerol and caprylic acid blends, the coefficient of variation was $11 \%$, a reasonable value considering the simplicity and convenience of the method, which could enable its use inside the production plant, close to the esterification reactor. When the method was applied for esterification reaction control, although a significant correlation was not clearly obtained by RSM, $77 \%$ of the data obtained neared the prediction line, which values were comprised into the interval between 50 and $100 \mathrm{mg} \mathrm{NaOH} / \mathrm{g}$.

\section{Acknowledgments}

The authors would like to thank CAPES (Coordenação de Aperfeiçoamento de Pessoal de Nível Superior), CNPq (Conselho Nacional de Desenvolvimento Científico e Tecnológico), FAPESP (Fundação de Amparo à Pesquisa do Estado de São Paulo), and Programa Santander de Bolsas de Iniciação Científica for the financial support.

\section{References}

AOCS, American Oil Chemists' Society, 2009. Official Methods and Recommended Practices of the AOCS. $6^{\text {a }}$ Edition, Champaign, USA.

Bentley, I. S., Williams, E. C. 1996. Starch conversion. In Industrial Enzymology. Godfrey T. and West, S., eds. $2^{\text {nd }}$ Edition, MacMillan Press LTD., New York, 339-358.

Blanco, S. F. M. M., Santos, J. S., Feltes, M. M. C., Dors, G., Licodiedoff, S., Lerin, L. A., Oliveira, D., Niniw, J. L., Furigo, A. 2015. Optimization of diacylglycerol production by glycerolysis of fish oil catalyzed by Lipozime TL IM with Tween 65. Bioproc. Biosyst. Eng. 38, 2379-2388.

Chang, S. S., Redondo-Solano, M., Thipparedd, I. H. 2010. Inactivation of Escherichia coli O157:H7 and Salmonella spp. on alfalfa seeds by caprylic acid and monocaprylin. Int. J. Food Microbiol. 144, 141-146.

Da Silva, M. A. M., Medeiros, V. C., Freire, D. M. G., Langone, M. A. P. 2003. Synthesis of monocapryn catalyzed by lipase. Appl. Biochem. Biotechnol. 108, 757-768.

Fowlie, J. S. 1969. Statistical tables for students. Oliver and Boyd, Edinburgh, UK.

Freitas, L., Santos, J. C., Barcza, M. V., Castro, H. F. 2009. Potential alternative for using the glycerol generated in the biodiesel production: enzymatic synthesis of monolaurin by esterification. Quim. Nova 32, 2277-2281.

Garcia, M., Amalaradjou, M. A. R., Nair, M. K. M., Annamalai, T., Surendranath, S., Lee, S., Hoagland, T., Dzurec, D., Faustman, C., Venkitanarayanan, K. 2007. 
Inactivation of Listeria monocytogenes on frankfurters by monocaprylin alone or in combination with acetic acid. J. Food Protect. 70, 1594-1599.

Godfrey, T. 1996. Protein modification. In Industrial Enzymology. Godfrey, T. and West, S., eds. $2^{\text {nd }}$ Edition, MacMillan Press LTD., New York, 301-326.

Guebara, S. A. B., Araújo, M. C. E., Ract, R. N. J., Vitolo, M. 2016. Lipase catalyzed esterification of caprylic acid with residual glycerol from biodiesel production. World J. Pharm. Sci. 4, 362-375.

Herrero, O. M., Moncalian, G., Alvares, H. M. 2016. Physiological and genetic differences amongst Rhodococcus species from using glycerol as a source for growth and triacylglycerol production. Microbiology-SGM, 162, 384-397.

Kaewthong, W., Sirisansaneeyakul, S., Prasertsan, P., H-kittikun, A. 2005. Continuous production of monoacylglycerols by glycerolysis of palm olein with immobilized lipase. Process Biochem. 40, 1525-1530.

Kamm, B., Kamm, M. 2007. Biorefineries-multi product processes. Adv. Biochem. Eng. Biot. 105, 175-204.

Kittikuon, A., Kaewthong, W., Cheirsilp, B. 2008. Continuous production of monoacylglycerols from palm olein in packed-bed reactor with immobilized lipase PS. Biochem. Eng. J. 40, 116-120.

Koh, S. P., Tan, C. P., Lai, O. M., Arifin, N., Yusoff, M. S. A., Long, K. 2010. Synthesis of medium- and long-chain triacylglycerols (MLCT): Optimization of process parameters using response surface methodology. Food Bioprocess Tech. 3, 288-299.

Levin, J. 1977. Elementary Statistics in social Research. $2^{\text {nd }}$ Edition, Harper \& Row Publishers Inc., New York, USA.

Machado, M. D., Perez-Pariente, J., Sastre, E., Cardoso, D., De Guerenu, A. M. 2000. Selective synthesis of glycerol monolaurate with zeolitic molecular sieves. Appl. Catal. A-Gen. 203, 321-328.

Marzuki, N. H. C., Mahat, N. A., Huyop, F., Aboul-Enein, H., Wahab, R. A. 2015. Sustainable production of the emulsifier methyl oleate by Candida rugosa lipase nanoconjugates. Food Bioprod. Process, 96, 211-220.

Medeiros, M. A., Leite, C. M. M., Lago, R. M. 2012. Use of glycerol by-product of biodiesel to produce an efficient dust suppressant. Chem. Eng. J. 180, 364-369.

Minovska, V., Winkelhausen, E., Kuzmanova, S. 2005. Lipase immobilized by different techniques on various support materials applied in oil hydrolysis. $J$. Serb. Chem. Soc. 70, 609-624.

Morrison, R. T. and Boyd, R. N. 1969. Organic Chemistry. Allyn and Bacon, Boston, USA.

Poppe, J. K., Fernandez-Lafuenter, R., Rodriguez, R. C., Ayub, M. A. Z. 2015. Enzymatic reactions for biodiesel synthesis: present status and future prospects. Biotechnol. Adv. 33, 511-525.

Rodrigues, M. I., Iemma, A. F. 2009. Experimental Planning and optimization of processes. Casa do Pão Editora, Campinas, Brazil.

Scrimgeour, C. M., Harwood, J. L. 2007. Fatty Acid and Lipid Structure. In The Lipid Handbook. Gunstone, F.D., Harwood, J.L., Dijkstra, A.J., eds. $3^{\text {rd }}$ Edition, CRC Press, Boca Raton, 1-36.

Silva, S. A. B., Araujo, M. C. E., Ract, J. R., Vitolo, M. 2015. Differential scanning calorimetry study on caprylins. J. Therm. Anal. Calorim. 120, 711-717.

Singh, A. K., Mukhopadhyay, M. 2014. Optimization of lipase-catalyzed glycerolysis for mon o and diglyceride production using response surface methodology. Arab. J. Sci. Eng., 39, 2463-2474. 
Solaesa, A. G., Sanz, M. T., Falkeborg, M., Beltrán, S., Guo, Z. 2016. Production and concentration of monoacylglycerols rich in omega-3 polyunsaturated fatty acids by enzymatic glycerolysis and molecular distillation. Food Chem. 190, 960-967.

Vltavska, P., Kasparkova, V., Janis, R., Bunkova, L. 2013. Antifungal and antibacterial effects of 1-monocaprylin on textile materials. Eur. J. Lipid Sci. Tech. 114, 849-856.

Xu, X., Skands, A. R. H., Hoy, C. E., Mu, H., Balchen, S., Adler-Nissen, J. 1998. Production of specific structured lipids by enzimatic interesterification: elucidation of acyl migration by response surface design. J. Am. Oil Chem. Soc. 75, 1179-1186.

Yang, T., Fruekilde, M. B., Xu, X. 2005. Suppression of acyl migration in enzymatic production of structured lipids through temperature programming. Food Chem. 92, 101-107.

Zhong, N., Cheong, L. Z., Xu, X. 2014. Strategies to obtain high content of monoacylglycerols. Eur. J. Lipid Sci. Technol. 116, 97-107. 